\title{
Jurist-Diction
}

Volume 4 No. 6 November 2021

\section{Pengawasan Dalam Kerja Sama Bank Umum dan Penyelenggara Layanan Pinjam Meminjam Uang Berbasis Teknologi Informasi}

\author{
Nabilla Virnanda Lobo \\ nabillalobo@gmail.com \\ Universitas Airlangga
}

How to cite:

Nabilla Virnanda

Lobo'Pengawasan Dalam

Kerja Sama Bank Umum dan

Penyelenggara Layanan Pinjam

Meminjam Uang Berbasis

Teknologi Informasi' (2021)

Vol. 4 No. 6 Jurist-Diction.

Histori artikel:

Submit 1 April 2021;

Diterima 15 Oktober 2021;

Diterbitkan 5 November 2021.

DOI:

10.20473/jd.v4i6.31851

p-ISSN: 2721-8392

e-ISSN: $2655-8297$

\section{Abstract}

Partnership is a collaboration between one party and another, where each party plays its respective roles in a reciprocal relationship that benefits each party. This research will discuss the characteristics of the forms of cooperation between commercial banks and information technology-based lending and borrowing service providers (fintech peer-to-peer lending) and then discusses the supervision of regulatory agencies on cooperation in the financial sector. This research is a doctrinal research using a statute approach and a conceptual approach to obtain a clearer picture. The result of this research is that credit distribution cooperation is carried out by taking into account the provisions regarding information technology-based lending and borrowing services while retail investment sales cooperation and nonperforming loan management cooperation are carried out by taking into account the provisions concerning banks and / or commercial banks as in the cooperation. commercial banks. The supervisory authority lies with the Financial Services Authority.

Keywords: Fintech P2PL; Commercial Banks; OJK.

\section{Abstrak}

Partnership adalah kerja sama antara satu pihak dengan pihak lainnya dimana masing-masing pihak menjalankan perannya masing-masing dalam hubungan timbal balik yang memberikan keuntungan kepada masing-masing pihak. Dalam penelitian ini akan dibahas mengenai karakteristik bentuk-bentuk kerja sama antara bank umum dengan penyelenggara layanan pinjam meminjam berbasis teknologi informasi (fintech peer-to-peer lending) kemudian membahas mengenai pengawasan lembaga otoritas terhadap kerja sama dalam sektor keuangan tersebut. Penelitian ini merupakan penelitian doctrinal research dengan menggunakan pendekatan perundangundangan (statute approach) dan pendekatan konseptual (conceptual approach) untuk memperoleh gambaran yang lebih jelas. Hasil dalam penelitian ini yaitu kerja sama penyaluran kredit dilaksanakan dengan memperhatikan ketentuan mengenai layanan pinjam meminjam uang berbasis teknologi informasi sedangkan kerja sama penjualan investasi ritel dan kerja sama pengelolaan non-performing loan dilaksanakan dengan memperhatikan ketentuan mengenai bank dan/ atau bank umum sebagaimana dalam kerja sama bank umum. Adapun kewenangan pengawasan berada di Otoritas Jasa Keuangan.

Kata Kunci: Fintech P2PL; Bank Umum; OJK.

Copyright $(\mathbb{C} 2021$ Nabilla Virnanda Lobo 


\section{Pendahuluan}

Kegiatan pinjam-meminjam atau lending telah ada sejak waktu yang sangat lama. Kegiatan tersebut telah ada terlebih dahulu sebelum munculnya mata uang formal dan sistem perbankan formal yang berlaku selama ribuan tahun. ${ }^{1}$ Dalam Kitab UndangUndang Hukum Perdata atau Burgerlijk Wetboek, Pasal 1754, pinjam-meminjam didefinisikan sebagai "suatu perjanjian dengan mana pihak yang satu memberikan kepada pihak yang lain suatu jumlah tertentu barang-barang yang menghabis karena pemakaian, dengan syarat bahwa pihak yang belakangan ini akan mengembalikan sejumlah yang sama dari macam dan keadaan yang sama pula". Selanjutnya menurut hukum Islam, "pinjam-meminjam atau dalam bahasa Arab disebut Al-Ariyah, menurut istilahnya dapat dikatakan sebagai suatu kegiatan muamalah yang memberikan manfaat sesuatu yang halal kepada orang lain untuk diambil manfaatnya, dengan tidak merusak zatnya agar zatnya tetap dapat dikembalikan kepada pemiliknya". ${ }^{2}$

Seperti yang kita ketahui, bank merupakan pelaku kegiatan pinjammeminjam yang utama dalam sejarah perekonomian dunia. Berdasarkan catatan sejarah, bank telah menjadi sentral perekonomian sejak berakhirnya masa Perang Dunia II, dimana pada masa itu terjadi resesi ekonomi yang mengakibatkan krisis finansial. ${ }^{3}$ Bank mulai meminjamkan uang ke negara-negara secara keseluruhan, dan perbankan ritel mulai menjadi sesuatu yang lumrah. ${ }^{4}$

Peminjaman uang dari bank biasa disebut kredit. Kredit lahir dari suatu perjanjian antara bank dengan nasabah debitur. Dalam membuat suatu perjanjian kredit, bank terikat oleh aturan-aturan baku yang dituangkan dalam peraturan perundang-undangan dan sangat berkaitan dengan kebijakan suatu negara. Sebagaimana di Indonesia, kredit diatur dalam Undang-Undang Nomor 7 Tahun

${ }^{1}$ Brett King, Breaking Banks, The Innovators, Rogues and Strategists Rebooting Banking (John Wiley \& Sons Singapore Pte.Ltd 2014).[21].

2 Jamaluddin, 'Konsekuensi Akad Al-Ariyah Dalam Fiqh Muamalah Maliyah Perspektif Ulama Madzahib Al-Arba'ah' (2015) 02 Jurnal Qawanin 2.[3].

3 Jose-Luis Peydro, 'Discussion Of "The Effect Of Bank Capital On Lending : What Do We Know and What Does It Mean?"'(2010) 06 International Journal Of Central Banking 4.[55].

4 Worldbank.org.ro, 'The History ofBanks', <https://www.worldbank.org.ro/about-banks-history>, dikunjungi pada tanggal 24 Oktober 2020, pukul 18.35 . 
1992 juncto Undang-Undang Nomor 10 Tahun 1998 Tentang Perbankan, Peraturan Bank Indonesia, Surat Edaran Bank Indonesia, Peraturan Otoritas Jasa Keuangan, serta Surat Edaran Otoritas Jasa Keuangan.

Dewasa ini, perkembangan teknologi pada sektor finansial atau Fintech semakin maju dan dikenal secara luas oleh masyarakat sejak hadirnya perusahaanperusahaan startup yang menggunakan bisnis model Fintech. Bisnis model Fintech yang dimaksud antara lain "account management, asset management, investments and savings, crowdfunding/crowdinvesting, cryptocurrencies, financial planning, insurance, lending and financing, payment and money transfer, peer-to-peer lending, trading, dan lainnya". ${ }^{5}$ Bisnis model Fintech dengan kegiatan pinjammeminjam adalah peer-to-peer lending. Peer-to-peer lending atau P2PL merupakan layanan untuk mempertemukan pemberi pinjaman atau kreditur dengan penerima pinjaman atau debitur tanpa proses dan struktur institusi tradisional. ${ }^{6}$

Penyelenggaraan bisnis model Fintech khususnya P2PL di Indonesia mendapat tempat yang leluasa karena kemudahan akses dan kebutuhan yang tinggi dari masyarakat. Kemudahan akses yaitu berkaitan dengan akses melalui media elektronik seperti smartphone/mobile phone, komputer, tab/ipad yang terhubung dengan jaringan internet. Indonesia merupakan negara dengan penetrasi mobile phone yang tinggi. ${ }^{7}$ Berdasarkan data Statista : Penterasi Ponsel Pintar di Indonesia, Juli 2020, pada Tahun 2018, lebih dari setengah populasi di Indonesia atau 56,2 persen telah menggunakan ponsel pintar (smartphone). ${ }^{8}$ Selanjutnya di Tahun 2019, pengguna ponsel pintar meningkat hingga mencapai 63,3 persen. ${ }^{9}$

${ }^{5}$ Ryan Randy Suryono, 'Financial Technology (FINTECH) Dalam Prespektif Aksiologi' (2019) 10 Jurnal Masyarakat Telematika Dan Informasi 1.[52].

${ }^{6}$ Carissa Akhlaq Mulia Purnomo, Penyelenggaraan Sistem Dan Transaksi Elektronik Peer To Peer Lending Yang Disediakan Oleh PT Amartha Mikro Fintek (Skripsi pada Program Sarjana Universitas Airlangga, Surabaya 2018).[22].

7 Deloitte, 'A Tale of 44 Cities - Connecting Global Fintech : Interim Hub Review 2017', $<$ https://www2.deloitte.com/content/dam/Deloitte/uk/Documents/Innovation/deloitte-uk-connecting-global-fintech-hub-federation-innotribe-innovate-finance.pdf $>$, dikunjungi pada tanggal $31 \mathrm{Ok}-$ tober 2020, pukul 16.20.

${ }^{8}$ Yosepha Pusparisa, 'Pengguna Smartphone Diperkirakan Mencapai 89\% Populasi Pada 2025', <https://databoks.katadata.co.id/datapublish/2020/09/15/penggunaan-smartphone-diperkirakan-mencapai-89-populasi-pada-2025>, dikunjungi pada tanggal 31 Oktober 2020, pukul 16.50.

9 ibid. 
Diperkirakan hingga tahun 2025, pengguna ponsel pintar di Indonesia

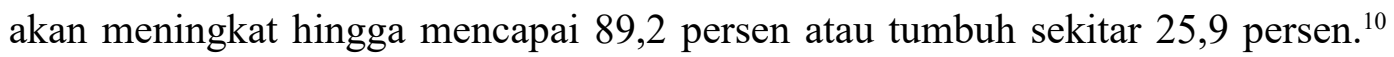
Kebutuhan yang tinggi dari masyarakat yaitu berkaitan dengan kebutuhan akan layanan finansial seperti kepemilikan rekening di bank, mendapatkan layanan kredit, melakukan investasi, mendapat layanan asuransi dan sebagainya. ${ }^{11}$ Berdasarkan hasil riset Bain \& Company yang berkolaborasi dengan Google dan Temasek, Fulfilling its Promise - The Future of SouthEast Asia's Digital Financial Services, Tahun 2019 menunjukan, "sebanyak 92 juta jiwa penduduk dewasa di Indonesia belum tersentuh layanan finansial". ${ }^{12}$ Selanjutnya, "baru 42 juta jiwa penduduk dewasa Indonesia yang mendapat layanan finansial, sedangkan 47 jutajiwa penduduk dewasa yang lain telah memiliki rekening bank tetapi belum mendapat layanan finansial lainnya". ${ }^{13}$

Kebutuhan akan layanan finansial khususnya kebutuhan akan layanan kredit di Indonesia berbenturan dengan analisis kredit yang dimiliki oleh bank dimana analisis kredit itu sangat berhubungan dengan kebijakan Pemerintah, kebijakan Bank Indonesia mengenai suku bunga, arah ekonomi Indonesia dan sebagainya. Sehingga nasabah sekalipun belum tentu creditworthy atau memenuhi persyaratan kredit yang dimiliki oleh bank (unbankable).${ }^{14}$ Di sisi lain, penyelenggaraan Fintech P2PL hadir dengan tujuan untuk menyentuh masyarakat yang belum tersentuh layanan finansial (unbanked population) dan masyarakat yang unbankable dengan menawarkan persyaratan yang mudah dipenuhi. ${ }^{15}$ Kemudahan Fintech P2PL untuk dijangkau oleh masyarakat mengakibatkan Fintech P2PL bertumbuh dengan pesat dan dianggap dapat mematikan usaha kredit yang dimiliki oleh bank. ${ }^{16}$

\footnotetext{
${ }^{10}$ ibid.

${ }^{11}$ Viva Budy Kusnandar, '92 Juta Penduduk Dewasa Indonesia Belum Tersentuh Layanan Finansial', <https://databoks.katadata.co.id/datapublish/2019/10/08/92-juta-penduduk-dewasa-indonesia-belum-tersentuh-layanan-finansial>, dikunjungi pada 31 Oktober 2020, pukul 18.00.

${ }^{12}$ ibid.

${ }^{13}$ ibid.

${ }^{14}$ Suhail Eresmair, 'Bank vs Fintech, Siapa Yang Akan Menang?', <https://www.google. com/amp/s/www.kompasiana.com/amp/suhailsuhail4643/5cc1591 da8bc1569e50ca0f2/bank-vsfintech-siapa-yang-akan-menang>, dikunjungi pada 12 November 2020, pukul 19.20.

${ }^{15}$ ibid.

16 ibid.
} 
Dalam praktek, kemudahan yang dimiliki Fintech P2PL justru membawa masalah bagi penyelenggaranya. Pemberian dana pinjaman tanpa agunan dan suku bunga tinggi yang ditawarkan memiliki risiko yang tinggi bagi keberlangsungan kegiatan pinjam-meminjam, dimana gagal bayar peminjam dana sering terjadi dan tidak ada backup yang dapat digunakan untuk menutup dana pemberi pinjaman. Sehingga kepercayaan sulit dibangun dan mengakibatkan penyelenggara Fintech P2PL menggunakan cara-cara yang melanggar hukum seperti mengancam/meneror peminjam dana, melarikan diri dari pemberi pinjaman dan sebagainya.

Di sisi lain, Bank Indonesia menerapkan kebijakan markoprudensial yang akomodatif untuk mendorong optimalisasi penyaluran kredit perbankan ke level 15 hingga 16 persen per tahun selama tiga hingga empat tahun ke depan yaitu 2019-2023. ${ }^{17}$ Padahal per April 2019, pertumbuhan kredit perbankan baru tumbuh sekitar 11,05 persen. ${ }^{18}$ Tuntutan kebijakan Bank Indonesia tersebut tidak sejajar dengan kemampuan bank untuk menjangkau masyarakat lebih luas khususnya bagi masyarakat di luar Pulau Jawa dan masyarakat yang tinggal di daerah pelosok. ${ }^{19}$

Hambatan-hambatan yang dimiliki baik oleh penyelenggara Fintech P2PL dan perbankan atau bank, memungkinkan bank dan penyelenggara Fintech P2PL melakukan kerjasama atau kolaborasi. Sebagaimana Ketua Bidang Pengkajian dan Pengembangan Perbanas, Aviliani mengatakan bahwa jika bank tidak berkolaborasi dengan Fintech, akan tergerus Net Interest Margin (NIM) nya. ${ }^{20}$

Dalam melakukan kerja sama, bank sebagai lembaga jasa keuangan tunduk pada pengaturan dan pengawasan OJK dalam aspek microprudential seperti kelembagaan, kegiatan usaha, dan penilaian lembaga kesehatan dan Bank Indonesia

\footnotetext{
${ }^{17}$ IpotNews, 'Kebijakan Makroprudensial Tetap Akomodatif Terhadap Perbankan 3-4 Tahun Ke Depan : BI', <https://www.indopremier.com/ipotnews/newsDetail.php?jdl=Kebijakan_Makroprudensial_Tetap_Akomodatif_Terhadap_Perbankan_3_4_Tahun_Ke_Depan BI\&news_id=106580\&group_news $=$ IPOTNEWS\&news_date $=\& \operatorname{tag}-\overline{-}-\overline{-}-{ }_{-}$subtype $=\overline{E C O N O M}-$ ICS\&name $=\&$ search $=y \_$general $\& q=$ kebijakan makro,perbankan\&halaman $=1>$, dikunjungi pada 12 November 2020, pukul 17.23.

${ }^{18}$ ibid.

${ }^{19}$ ibid.

${ }^{20}$ CNBC Indonesia TV, 'Ekonom Nilai Kolaborasi Fintech \& Bank Akan Menguntungkan', $<$ https://www.cnbcindonesia.com/tech/20191008155055-39-105301/ekonom-nilai-kolaborasi-fintech-bank-akan-menguntung>, dikunjungi pada 11 September 2020, pukul 15.22.
} 
dalam aspek macroprudential seperti ketentuan tentang Giro Wajib Minimum (GWM), ketentuan devisa, Operasi Pasar Terbuka (OPT) dan laporan-laporan serta pemeriksaan yang terkait dengan pelaksanaan tugas di bidang moneter dan sistem pembayaran. ${ }^{21}$ Adapun pada Peraturan OJK seperti Peraturan OJK Nomor 6/ POJK.03/2016 Tentang Kegiatan Usaha dan Jaringan Kantor Berdasarkan Modal Inti Bank, serta peraturan lain yang terkait dengan kegiatan kerja sama bank, ataupun pada Peraturan Bank Indonesia seperti Peraturan Bank Indonesia Nomor 13/27/PBI/2011 Tentang Perubahan Atas Peraturan Bank Indonesia Nomor 11/1/ PBI/2009 Tentang Bank Umum, serta peraturan lain yang terkait dengan kegiatan kerja sama bank, tidak diatur secara tegas mengenai kerja sama bank dengan penyelenggara Fintech P2PL. Hal tersebut menimbulkan permasalahan hukum, karena tanpa pengaturan yang tegas, bank dan penyelenggara Fintech P2PL akan melakukan kerja sama sebagaimana keinginan masing-masing pihak tanpa adanya pengawasan dari lembaga otoritas. Sedangkan, pengawasan itu sangat diperlukan mengingat kerja sama bank dengan penyelenggara Fintech P2PL adalah kerja sama dalam sektor keuangan. Sehingga perlu dilakukan analisis karakteristik kerja sama antara bank dengan penyelenggara Fintech P2PL. Selanjutnya akan dianalisis mengenai pengawasan dalam kerja sama antara bank dengan penyelenggara Fintech P2PL tersebut. Analisis akan dilakukan terbatas pada bank umum.

\section{Metode Penelitian}

Penelitian ini menggunakan tipe penelitian doctrinal research. Kemudian pendekatan masalah yang digunakan secara umum adalah pendekatan perundangundangan (statute approach). Digunakan pula pendekatan konseptual (conceptual approach) agar memperoleh gambaran yang lebih jelas. Bahan-bahan penelitian berupa bahan hukum primer dan bahan hukum sekunder. Bahan hukum primer berupa peraturan perundang-undangan. Bahan hukum sekunder berupa buku, jurnal, skripsi, tesis, disertasi yang berkaitan dengan asas-asas perbankan, perbedaan

\footnotetext{
${ }^{21}$ Ichsan Ferdinan S, 'Kewenangan Bank Indonesia Setelah Disahkan Undang-Undang Nomor 21 Tahun 2011 Tentang Otoritas Jasa Keuangan’ (2013) Private Law.[11].
} 
karakteristik bank dan Fintech Peer-to-Peer Lending, penyelenggaraan Fintech Peer-to-Peer Lending, pengawasan bank, pengawasan Fintech Peer-to-Peer Lending, perkembangan Fintech Peer-to-Peer Lending dan digitalisasi perbankan, konsep hubungan hukum, konsep perjanjian dan hal-hal lain yang berkaitan dengan rumusan masalah. Bahan-bahan hukum tersebut dikumpulkan melalui penelitian kepustakaan (library research) di perpustakaan Universitas Airlangga, koleksi khusus Fakultas Hukum Universitas Airlangga dan google play books.

\section{Karakteristik Kerja Sama Bank Umum dengan Penyelenggara Fintech Peer- to-Peer Lending}

Dalam dunia bisnis, dikenal istilah partnership. Secara bahasa, partnership disamakan (bersinonim) dengan cooperation, collaboration, relationship, dan sebagainya. ${ }^{22}$ Adapun menurut Black's Law Dictionary, partnership adalah " $a$ voluntary association of two or more persons who jointly own and carry on a business for profit". ${ }^{23}$

Pada penulisan ini, akan diuraikan bentuk-bentuk kerja sama antara bank dengan penyelenggara Fintech P2PL yang telah dibahas pada latar belakang yaitu 1. Kerja sama Penyaluran Kredit (Collaborate in Lending);

2. Kerja sama Penjualan Investasi Ritel (Ritel Investment);

3. Kerja sama pengelolaan Non Performing Loan(NPL).

Dengan menggunakan metode interpretasi yaitu:

1. Gramatikal (objektif): merupakan penafsiran menurut bahasa;

2. Otentik: merupakan penafsiran menurut batasan yang dicantumkan dalam peraturan itu sendiri;

3. Teleologis(sosiologis):merupakan penafsiranberdasarkantujuankemasyarakatan (pragmatis);

4. Sistematis (logis): merupakan penafsiran yang mengaitkan suatu peraturan dengan peraturan lainnya;

5. Historis (subjektif): merupakan penafsiran dengan menyimak latar belakang

\footnotetext{
${ }^{22}$ Google, 'Partnership Meaning (definisi dari Oxford Languages)', <www.google.com>, dikunjungi pada 1 Desember 2020, pukul 16.30.

${ }^{23}$ Bryan A Garner (Ed.), Black's Law Dictionary Eight Edition (Thomas Reuters 2004). [3544].
} 
sejarah hukum suatu ketentuan tertentu;

6. Komparatif: merupakan penafsiran dengan cara memperbandingkan peraturan pada suatu sistem hukum lain;

7. Fituristis (antisipatif): merupakan penafsiran dengan mengacu kepada rumusan dalam rancangan undang-undang atau rumusan yang di cita-citakan (ius constituendum);

8. Restriktif: merupakan penafsiran dengan membatasi cakupan suatu ketentuan; atau

9. Ekstensif: merupakan penafsiran dengan memperluas cakupan suatu ketentuan. ${ }^{24}$

dan dengan pendekatan Peraturan OJK Nomor 77/POJK.01/2016 Tentang Layanan

Pinjam Meminjam Uang Berbasis Teknologi Informasi, Peraturan-Peraturan yang mengatur kerja sama bank/produk dan aktivitas bank, serta Peraturan lain yang terkait.

\section{Kerja Sama Penyaluran Kredit (Collaborate in Lending)}

Menurut Peraturan OJK Nomor 77/POJK.01/2016 Tentang Layanan Pinjam Meminjam Uang Berbasis Teknologi Informasi, Pasal 1 angka 8, pemberi pinjaman adalah orang, badan hukum, dan/atau badan usaha yang mempunyai piutang karena perjanjian layanan pinjam meminjam uang berbasis teknologi informasi. Yang dimaksud dengan pemberi pinjaman, menurut Pasal 16 ayat (2), terdiri dari:

a. orang perseorangan warga negara Indonesia;

b. orang perseorangan warga negara asing;

c. badan hukum Indonesia/asing;

d. badan usaha Indonesia/asing; dan/atau

e. lembaga internasional.

Adapun yang dimaksud perjanjian layanan pinjam meminjam uang berbasis teknologi informasi, menurut Pasal 18 meliputi :

a. perjanjian antara penyelenggara dengan pemberi pinjaman; dan

b. perjanjian antara pemberi pinjaman dengan penerima pinjaman.

Menurut Pasal 19, perjanjian penyelenggaraan layanan pinjam meminjam uang berbasis teknologi informasi antara penyelenggara dengan pemberi pinjaman

\footnotetext{
${ }^{24}$ Sitti Mawar, 'Metode Penemuan Hukum (Interpretasi dan Konstruksi) Dalam Rangka Harmonisasi Hukum', <https://jurnal.ar-raniry.ac.id/index.php/justisia/article/download $>$ dikunjungi pada 22 Desember 2020, pukul 17.20.
} 
dituangkan dalam dokumen elektronik yang paling sedikit memuat:

a. Nomor perjanjian;

b. Tanggal perjanjian;

c. Identitas para pihak;

d. Ketentuan mengenai hak dan kewajiban para pihak;

e. Jumlah pinjaman;

f. Suku bungan pinjaman;

g. Besarnya komisi;

h. Jangka waktu;

i. Rincian biaya terkait;

j. Ketentuan mengenai denda (jika ada);

k. Mekanisme penyelesaian sengketa; dan

l. Mekanisme penyelesaian dalam hal penyelenggara tidak dapat melanjutkan kegiatan operasionalnya.

Dalam perjanjian antara penyelenggara dengan pemberi pinjaman, penyelenggara diberi kuasa untuk mewakili dan bertindak untuk dan atas nama pemberi pinjaman untuk menyelenggarakan suatu urusan. ${ }^{25}$ Perjanjian tersebut dapat dikategorikan sebagai perjanjian pemberian kuasa sebagaimana diatur dalam Pasal 1792 BW yaitu "perjanjian dengan mana seorang memberikan kekuasaan kepada seorang lain, yang menerimanya, untuk dan atas namanya menyelenggarakan suatu urusan". ${ }^{26}$ Selain itu, dalam perjanjian tersebut, diperjanjikan pula besaran komisi dimana pada perjanjian pemberian kuasa, juga terdapat upah apabila diperjanjikan sebagaimana diatur dalam Pasal 1794 BW yaitu, "pemberian kuasa terjadi dengan cuma-cuma kecuali jika diperjanjikan sebaliknya....". ${ }^{27}$

Menurut Undang-Undang Perbankan, Pasal 1 angka 2, "bank adalah badan usaha yang menghimpun dana dari masyarakat dalam bentuk simpanan dan menyalurkannya kepada masyarakat dalam bentuk kredit dan atau bentuk-bentuk lainnya dalam rangka meningkatkan taraf hidup rakyat banyak". Sehingga bank merupakan pihak yang masuk dalam kriteria pemberi pinjaman dalam POJK 77/ POJK.01/2016. Kemudian apabila konstruksi hubungan hukum dan klausula

${ }^{25}$ Airin, Perbandingan Karakteristik Layanan Pinjam Meminjam Uang Berbasis Teknologi Informasi (Financial Technology Peer To Peer Lending) Dengan Perbankan (Skripsi Pada Program Sarjana Universitas Airlangga 2017).[49].

${ }^{26} \mathrm{ibid}$.

${ }^{27}$ ibid. 
perjanjian antara penyelenggara dengan pemberi pinjaman dianalisis dengan membandingkannya dengan kerja sama bank umum dalam kerja sama agen penjual reksa dana, kerja sama agen penjual SBN, kerja sama bancassurance dan kerja sama payment point dapat dikatakan bahwa perjanjian antara penyelenggara dengan pemberi pinjaman adalah kontrak kerja sama.

Menurut Pasal 20, perjanjian pemberian pinjaman antara pemberi pinjaman dengan penerima pinjaman dituangkan dalam dokumen elektronik yang paling sedikit memuat:

a. Nomor perjanjian;

b. Tanggal perjanjian;

c. Identitas para pihak;

d. Ketentuan mengenai hak dan kewajiban para pihak;

e. Jumlah pinjaman;

f. Suku bunga pinjaman;

g. Nilai angsuran;

h. Jangka waktu;

i. Objek jaminan (jika ada);

j. Rincian biaya terkait;

k. Ketentuan mengenai denda (jika ada); dan

1. Mekanisme penyelesaian sengketa.

Perjanjian pemberian pinjaman, berdasarkan contoh perjanjian pinjaman yang dikeluarkan oleh salah satu penyelenggara Fintech P2PL yaitu PT Investree Radhika $\mathrm{Jaya}^{28}$ memiliki karakteristik:

1. bersifat konsensuil, yaitu perjanjian tersebut telah lahir sejak adanya kesepakatan dari para pihak yang diwujudkan dalam bentuk ditandatanganinya perjanjian oleh para pihak;

2. Adanya tujuan penggunaan dana pinjaman, pada marketplace Investree, tujuan penggunaan dana pinjaman dikategorikan menjadi 2 (dua) yaitu pinjaman personal seperti renovasi rumah, pendidikan, berlibur, pernikahan, biaya kesehatan, dan kendaraan bermotor dan pinjaman bisnis seperti invoice financing (pembiayaan tagihan) dan online seller financing (pembiayaan bisnis online). Tujuan penggunaan/pemanfaatan dana diatur dalam Pasal 19 ayat (3) Jo ayat (5)

${ }^{28}$ ibid. [52]. 
POJK 77.01/2016 dimana penyelenggara wajib menyediakan akses informasi kepada pemberi pinjaman atas penggunaan dananya.

Sehingga perjanjian pemberian pinjaman dikategorikan sebagai perjanjian kredit. ${ }^{29}$ Selanjutnya, menurut Pasal 19 ayat (3) jo Pasal 19 ayat (5) POJK 77.01/2016, penyelenggara wajib menyediakan akses informasi kepada pemberi pinjaman atas penggunaan dananya, informasi tersebut paling sedikit memuat:

a. Jumlah dana yang dipinjamkan kepada penerima pinjaman;

b. Tujuan pemanfaatan dana oleh penerima pinjaman;

c. Besaran bunga pinjaman; dan

d. Jangka waktu pinjaman.

Adapun akses informasi tersebut, menurut Pasal 19 ayat (4) tidak termasuk informasi terkait identitas penerima pinjaman.

Untuk menjelaskan ketentuan Pasal 19 ayat (3) tersebut, penulis mengutip contoh dari perjanjian penyelenggaraan KoinWorks mengenai klausula urusan yang diselenggarakan penyelenggara KoinWorks untuk dan atas nama pemberi pinjaman, yaitu:

a. Membuat, mengajukan, dan menandatangani perjanjian kredit dengan yang terdaftar platform sehubungan dengan pemberian pinjaman oleh pemberi kuasa kepada melalui platform milik penerima kuasa.

b. Memberikan kuasa subtitusi atau penugasan kepada karyawan dari penerima kuasa sehubungan dengan teknis pelaksanaan kuasa ini.

c. Mentransfer, mengalihkan dan/atau mencairkan dana pinjaman atas nama pemberi kuasa kepada, dan sebaliknya mentransfer, mengalihkan dan/atau mencairkan pengembalian pinjaman oleh kepada pemberi kuasa-seluruhnya atas instruksi sebelumnya dari pemberi kuasa.

d. Membebankan atau memotong secara otomatis biaya jasa yang menjadi hak penerima kuasa atas jasa penyediaan platform dan konsultasi bisnis kepada pemberi kuasa dari dana yang tersimpan di dalam rekening bersama sesuai syarat dan ketentuan.

e. Mengambil tindakan lain yang dianggap perlu untuk kepentingan pemberi kuasa sehubungan dengan pemberian pinjaman kepada melalui platform tersebut, termasuk namun tidak terbatas pada menghadap dan berkomunikasi dengan dan/atau kuasanya dan/atau pihak lainnya yang terkait antara lain seperti bank, notaris, dan lain-lain; menentukan persyaratan yang diperlukan kepada atas nama; menyerahkan dan/atau menerima dokumen baik asli maupun salinannya

${ }^{29}$ ibid. [54]. 
dalam bentuk hard copy atau scan dari dan kepada pemberi kuasa, dan/atau pihak lainnya; ${ }^{30}$

Mengenai poin a dan c tersebut, penulis merujuk pada cara kerja layanan Fintech P2PL bagi pemberi pinjaman yang disediakan di website Investree: ${ }^{31}$

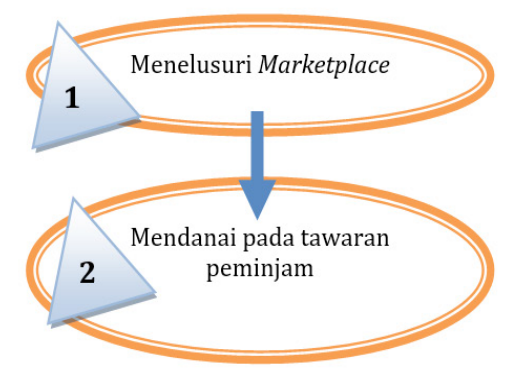

Secara bertahap, apabila pemberi pinjaman ingin melakukan pemberian pinjaman, langkah pertama adalah menelusuri marketplace Investree. ${ }^{32}$ Dalam penelusuran tersebut, pemberi pinjaman melakukan analisis pinjaman yang diajukan penerima pinjaman berdasarkan informasi yang tertera di fact sheet. ${ }^{33}$ Langkah kedua, pemberi pinjaman menentukan jumlah pendanaan pada tawaran pinjaman yang ia pilih. ${ }^{34}$ Adapun informasi yang tertera di fact sheet tersebut merupakan informasi tentang penerima pinjaman yang telah melalui serangkaian tahapan. Tahapan tersebut yaitu:

1. Calon penerima pinjaman mengajukan pinjaman dengan cara melengkapi informasi yang dibutuhkan pada aplikasi pinjaman;

2. Tim Investree melakukan analisis terhadap informasi yang diajukan tersebut dan untuk selanjutnya menyetujui aplikasi pinjaman sebelum ditawarkan kepada pemberi pinjaman. ${ }^{35}$

Apabila pengaturan dalam Pasal 19 POJK 77.01/2016, uraian penjelasan Pasal 19 ayat (3), dan perjanjian pemberian pinjaman dikategorikan sebagai perjanjian

\footnotetext{
${ }^{30}$ ibid. [50].

${ }^{31}$ Investree, 'Bagaimana Cara Kerja Peer-to-Peer Lending?', <https://investree.id/how-itworks>, dikunjungi pada 21 Desember 2020, pukul 18.30.

${ }^{32}$ ibid.

${ }^{33}$ ibid.

${ }^{34}$ ibid.

35 ibid.
} 
kredit dikaitkan dengan perjanjian kredit sebagaimana diatur dalam UndangUndang Perbankan, jelas terlihat perbedaan dalam kedua perjanjian tersebut yaitu dalam perjanjian kredit bank, dalam memberikan kredit, menurut Pasal 8 UndangUndang Perbankan, bank memperhatikan asas-asas perkreditan bank yaitu prinsip kepercayaan $^{36}$ (fiduciary principle), prinsip kerahasiaan (confidential principle), prinsip kehati-hatian (prudential principle), dan prinsip mengenal nasabah (know your customer principle) dengan melakukan analisis 5C yaitu character (watak), capacity (kemampuan), capital (modal), collateral (agunan), dan condition (prospek usaha dari debitur), sedangkan dalam perjanjian kredit melalui layanan Fintech P2PL, pemberi pinjaman memberikan pinjaman berdasarkan analisis terbatas pada yang tertera dalam fact sheet atau informasi aplikasi pinjaman yang diajukan penerima pinjaman. Sehingga dapat disimpulkan bahwa kerja sama penyaluran kredit antara penyelenggara Fintech P2PL dengan bank umum dimana bank sebagai pihak pemberi pinjaman bukan termasuk kerja sama penyaluran kredit oleh bank umum, melainkan hanya kerja sama antara pemberi pinjaman dengan penyelenggara Fintech P2PL.

\section{Kerja Sama Penjualan Investasi Ritel (Ritel Investment)}

Menurut Halim, “investasi merupakan penempatan sejumlah dana pada saat ini dengan harapan akan dapat memberikan hasil atau keuntungan di masa yang akan datang". ${ }^{37}$ Pada umumnya investasi dibedakan menjadi investasi pada asetaset finansial, yaitu investasi yang dapat dilakukan di pasar uang seperti di sertifikat deposito, surat berharga pasar uang, commercial paper, dan investasi di pasar modal yang meliputi saham, obligasi, waran, dan sebagainya; dan investasi pada aset-aset riil yaitu investasi yang dapat berbentuk pendirian pabrik, perkebunan, pertambangan, dan pembelian aset produktif lainnya. ${ }^{38}$ Menurut SEOJK 27/

\footnotetext{
${ }^{36}$ Trisadini Prasastinah Usanti dan Abd. Shomad, Op.Cit.[19].

${ }^{37}$ Tati Febriyanti, Optimasi Portofolio Investasi Dana Syariah (Tesis Pada Program Pascasarjana Universitas Indonesia 2009).[13].

${ }^{38}$ ibid.
} 
SEOJK.03/2016, Bagian II Kegiatan Usaha Bank Umum, Huruf A Nomor 2, produk bank adalah instrumen keuangan yang diterbitkan oleh bank. produk yang dimaksud adalah produk yang diciptakan, diterbitkan, dan/atau dikembangkan oleh bank yang terkait dengan kegiatan penghimpunan dan penyaluran dana.

Dalam kegiatan penghimpunan dana, bank menerbitkan produk giro, tabungan, deposito, sertifikat deposito, surat utang termasuk surat utang dengan fitur ekuitas dan sebagainya. Sedangkan dalam kegiatan penyaluran dana, bank menerbitkan produk kredit, kredit sindikasi, bank garansi dan sebagainya. Kemudian menurut Undang-Undang Perbankan, Pasal 6 tentang usaha bank umum, huruf d : membeli, menjual atau menjamin atas risiko sendiri maupun untuk kepentingan dan atas perintah nasabahnya:

1. Surat-surat wesel termasuk wesel yang diakseptasi oleh bank yang masa berlakunya tidak lebih lama daripada kebiasaan dalam perdagangan surat-surat dimaksud;

2. Surat pengakuan hutang dan kertas dagang lainnya yang masa berlakunya tidak lebih lama dari kebiasaan dalam perdagangan surat-surat dimaksud;

3. Kertas perbendaharaan negara dan surat jaminan pemerintah;

4. Sertifikat Bank Indonesia (SBI);

5. Obligasi;

6. Surat dagang berjangka waktu sampai dengan 1 (satu) tahun;

7. Instrumen surat berharga lain yang berjangka waktu sampai dengan 1 (satu) tahun.

Kemudian merujuk pada Undang-Undang Nomor 8 Tahun 1995 Tentang Pasar Modal, dikaitkan dengan kegiatan usaha bank - keagenan dan kerjasama, bank merupakan pelaku pasar modal, yaitu sebagai perantara pedagang efek (agen penjual SBN), kustodian, agen penjual reksa dana, wali amanat dan sebagainya.

Berdasarkan uraian tersebut, diketahui bahwa bank menjual produk investasi baik yang ia terbitkan yaitu surat pengakuan utang maupun berdasarkan kontrak kerja sama yaitu reksa dana, surat berharga negara, dan sebagainya. Kerja sama bank dengan penyelenggara Fintech P2PL untuk menawarkan dan mendistribusikan produk-produk investasi memiliki konstruksi : bank melalui situs penyelenggara Fintech P2PL menawarkan produk investasi kepada pihak pemberi pinjaman dimana disertai pula fasilitas untuk berinteraksi dengan bank mengenai pembelian produk-produk investasi tersebut. Konstruksi ini memiliki skema sebagai berikut: 
Skema 1. Kerja Sama Penjualan Investasi Ritel

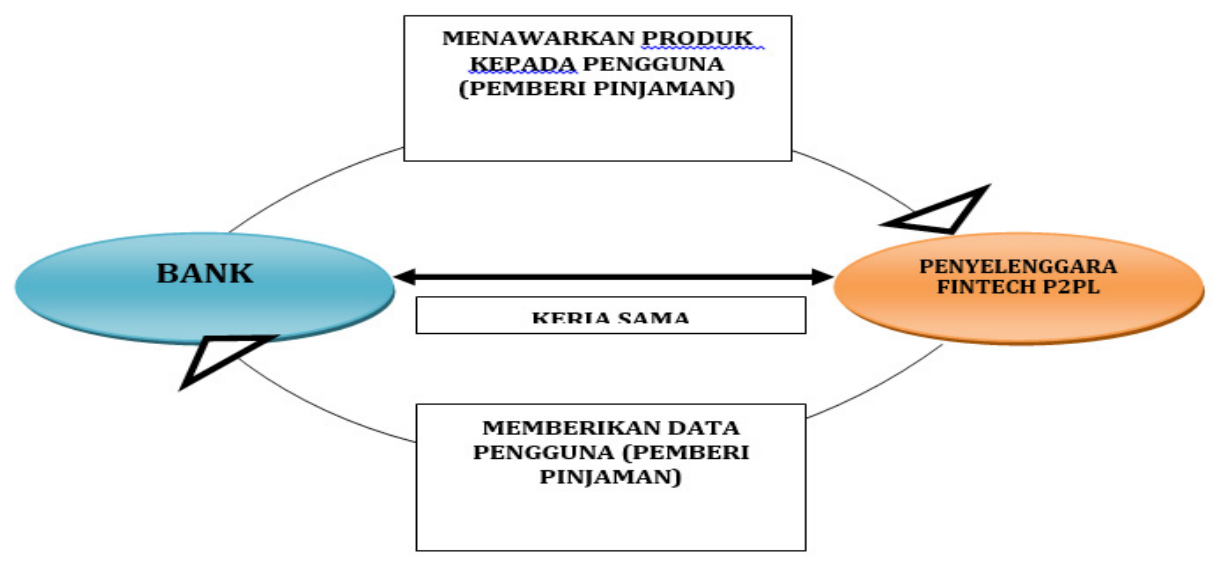

Konstruksi ini sesuai dengan ketentuan layanan transaksional dalam penjelasan POJK 12/POJK.03/2018 Tentang Penyelenggaraan Layanan Digital Oleh Bank Umum, Pasal 13 ayat (1) huruf b yaitu:

"yang dimaksud dengan "layanan transaksional" adalah layanan yang diawali dengan penyediaan informasi kepada nasabah bank yang dapat disertai dengan fasilitas untuk berinteraksi dengan bank dalam rangka membantu pengambilan keputusan transaksi keuangan sesuai dengan kebutuhan dan kemampuan nasabah, sebelum dilakukannya eksekusi transaksi oleh nasabah. Penyediaan informasi kepada nasabah antara lain:

1. Didasarkan pada hasil analisis bank terhadap portofolio nasabah;

2. Bersifat personal atau spesifik sesuai dengan karakteristik dan kebutuhan nansabah".

sehingga informasi yang disediakan bank untuk satu nasabah dengan nasabah yang lain dapat berbeda. contoh layanan transaksional dalam penjelasan Pasal 15 ayat

(1) huruf b yaitu:

"Bank "D" bekerja sama dengan PT "JKL" yang menyediakan situs market place. Aplikasi dan/atau situs web Bank " $\mathrm{D}$ " terhubung dengan situs PT "JKL" untuk menyajikan informasi produk komersial yang dijualtitipkan pada situs PT "JKL" kepada nasabah. informasi produk komersial yang disajikan kepada nasabah merupakan informasi yang bersifat personal berdasarkan hasil analisis bank terhadap perilaku belanja dan pembayaran nasabah serta posisi keuangan nasabah. Dalam hal nasabah berminat melakukan pembelian, apliaksi dan/atau situs web Bank "D" menyediakan fasilitas pembayaran".

Berkenaan dengan analisis bank terhadap perilaku belanja dan pembayaran nasabah serta posisi keuangan nasabah, bank dapat bekerja sama dengan 
penyelenggara Fintech P2PL dalam hal pertukaran data sebagaimana dalam FAQ Peraturan OJK Nomor 77/POJK.01/2016 Tentang Layanan Pinjam Meminjam Uang Berbasis Teknologi Informasi Kategori Perusahaan Penyelenggara yang dikeluarkan oleh OJK,

"penyelenggara Fintech Lending dapat bekerjasama dan melakukan pertukaran data dengan perusahaan lembaga jasa keuangan dan/atau perusahaan penyelenggara layanan pendukung berbasis teknologi informasi, yang telah mendapatkan izin usaha atau rekomendasi dari instansi yang berwenang dalam menjalankan kegiatan usahanya".

Akan tetapi kerja sama tersebut harus memperhatikan kewajiban penyelenggara Fintech P2PL sebagaimana diatur dalam Pasal 26 huruf c POJK 77/ POJK.01/2016, untuk "menjamin bahwa perolehan, penggunaan, pemanfaatan dan pengungkapan data pribadi, data transaksi, dan data keuangan yang diperoleh penyelenggara berdasarkan persetujuan pemilik data pribadi, data transaksi, dan data keuangan....”.

Sehingga apabila disimpulkan, kerja sama antara bank dengan penyelenggara Fintech P2PL dalam hal penjualan produk investasi oleh bank disini merupakan kerja sama perpaduan antara kerja sama penyediaan layanan perbankan digital dan kerja sama pertukaran data.

\section{Kerja Sama Pengelolaan Non-Performing Loan (NPL)}

Non-Performing Loan merupakan rasio perbandingan antara jumlah kredit yang diberikan dengan kolektibilitas kurang lancar, diragukan, dan macet dibandingkan dengan total kredit. ${ }^{39}$ Yang dimaksud dengan kerja sama antara bank dengan penyelenggara Fintech P2PL dalam pengelolaan NPL adalah penyelenggara Fintech P2PL "memberikan" pembiayaan kepada nasabah bank yang berpotensi NPL dimana pembiayaan tersebut digunakan untuk membantu bank dalam merestrukturisasi kredit.

${ }^{39}$ Selamet Riyadi, 'Muhammad Iqbal dan Novia Lauren, Strategi Pengelolaan Non Performing Loan Bank Umum Yang Go Public' (2015) 06 Jurnal Dinamika Manajemen 1.[86]. 


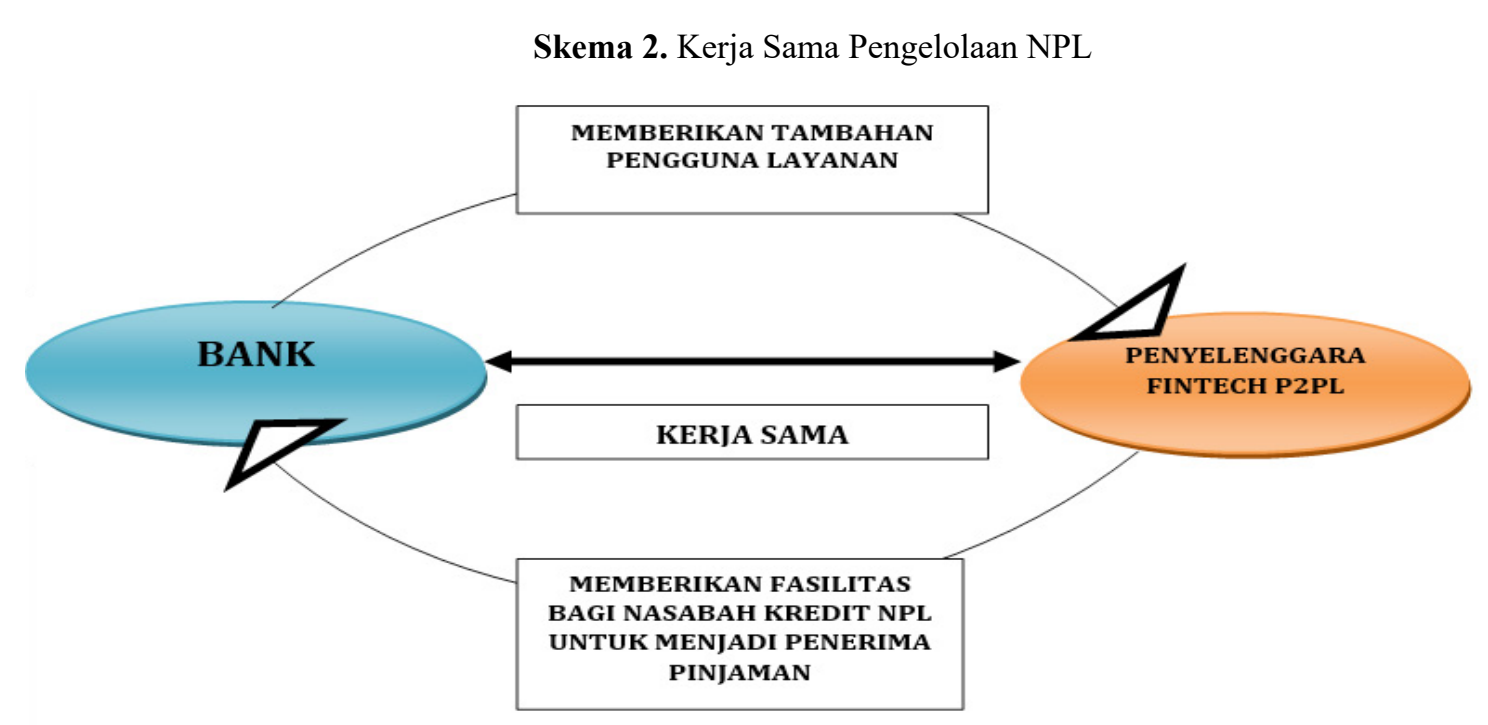

Source: diambil dari berbagai sumber.

Berdasarkan skema tersebut, yang dimaksud dengan penyelenggara Fintech P2PL memberikan pembiayaan adalah pemberian fasilitas kepada nasabah bank untuk menjadi penerima pinjaman dalam layanan Fintech P2PL dimana pinjaman yang didapatkan oleh nasabah tersebut akan digunakan untuk membayar tunggakan kredit di bank. Di sisi lain, bank memberikan tambahan pengguna layanan Fintech P2PL bagi penyelenggara Fintech P2PL.

Penulis menganalisis kerja sama tersebut berdasarkan ketentuan Peraturan OJK Nomor 18/POJK.03/2016 Tentang Penerapan Manajemen Risiko Bagi Bank Umum dan Surat Edaran OJK Nomor 27/SEOJK.03/2016 Tentang Kegiatan Usaha Bank Umum Berdasarkan Modal Inti yang mengatur tentang produk dan aktivitas baru bank. menurut Pasal 20 ayat (3) POJK 18/POJK.03/2016, produk atau aktivitas bank merupakan suatu produk baru atau aktivitas baru jika memenuhi kriteria :

a. Tidak pernah diterbitkan atau dilakukan sebelumnya oleh bank; atau

b. Telah diterbitkan atau dilaksanakan sebelumnya oleh bank namun dilakukan pengembangan yang mengubah atau meningkatkan eksposur risiko tertentu pada bank.

Dalam penjelasan Pasalnya, mengenai produk atau aktivitas pada huruf a, tidak diberikan definisi mengenai kalimat "tidak pernah diterbitkan atau dilakukan 
sebelumnya". Melainkan, diberikan suatu contoh bahwa apabila terdapat suatu bank yang menerbitkan produk atau melakukan aktivitas bank yang tidak pernah ia lakukan sebelumnya, tetapi sudah dilakukan oleh bank lain, maka itu dianggap produk atau aktivitas baru yang memenuhi kriteria huruf a. Sedangkan mengenai produk atau aktivitas pada huruf $\mathrm{b}$, dijelaskan mengenai perubahan eksposur risikonya, bahwa perubahan eksposur risiko yang dimaksud dalam pengaturan huruf b tidak mencakup perubahan eksposur risiko yang terkait produk atau aktivitas konvensional seperti giro, tabungan, deposito, kredit, produk derivatif yang bersifat plain vanilla ("transaksi derivatif valuta asing terhadap rupiah yang standar"40) dan aktivitas kustodian. ${ }^{41}$

Selanjutnya menurut SEOJK 27/SEOJK.03/2016, Bagian III Penerbitan Produk dan/atau Pelaksanaan Aktivitas Bank Umum, Huruf A, bank umum dapat menerbitkan produk dan/atau pelaksanaan aktivitas yang termasuk dalam kegiatan usaha bank umum dengan ketentuan sebagai berikut :

1. Penerbitan produk dan/atau pelaksanaan aktivitas yang merupakan produk dan/ atau aktivitas yang diperkenankan pada masing-masing BUKU;

2. Rencana penerbitan produk yang belum pernah diterbitkan dan/atau rencana pelaksanaan aktivitas yang belum pernah dilaksanakan sebelumnya dicantumkan dalam rencana bisnis bank untuk tahun yang sama dengan rencana penerbitan produk dan/atau rencana pelaksanaan aktivitas tersebut;

3. Penerbitan produk dan/atau pelaksanaan aktivitas yang merupakan produk dan/ atau aktivitas dasar tidak memerlukan persetujuan dari OJK;

4. Penerbitan produk dan/atau pelaksanaan aktivitas baru yang bukan merupakan produk dan/atau aktivitas dasar dan/atau memiliki risiko kompleksitas tinggi, terlebih dahulu memperoleh persetujuan dari OJK;

5. Bank menerapkan manajemen risiko yang memadai untuk memitigasi risiko yang ditimbulkan oleh penerbitan produk dan/atau pelaksanaan aktivitas sesuai POJK mengenai penerapan manajemen risiko bagi bank umum.

Apabila dilakukan interpretasi dengan metode sistematis, yang dimaksud dengan produk yang tidak pernah diterbitkan atau aktivitas yang tidak pernah

\footnotetext{
${ }^{40}$ Nina Dwiantika, 'BI Minta Nasabah Bank Gunakan Transaksi Derivatif', < https://www. google.com/amp/s/amp.kontan.co.id/news/bi-minta-nasabah-bank-gunakan-transaksi-derivatif>, dikunjungi pada 29 Desember 2020, pukul 17.50.

${ }^{41}$ Nina Dwiantika, 'BI Minta Nasabah Bank Gunakan Transaksi Derivatif', <https://www. google.com/amp/s/amp.kontan.co.id/news/bi-minta-nasabah-bank-gunakan-transaksi-derivatif>, dikunjungi pada 29 Desember 2020, pukul 17.50 .
} 
dilakukan sebelumnya oleh bankadalah produk atau aktivitas bank yang termasuk dalam perencanaan penerbitan produk atau pelaksanaan aktivitas yang tidak pernah dilakukan sebelumnya oleh bank yang harus dicantumkan dalam Rencana Bisnis Bank. Adapun menurut ketentuan SEOJK 27/SEOJK.03/2016, Bagian III Penerbitan Produk dan/atau Pelaksanaan Aktivitas Bank Umum, Huruf B Nomor 4, rencana penerbitan produk dan/atau aktivitas bank yang dicantumkan dalam RBB menggunakan format sebagaimana dimaksud pada Lampiran III SEOJK ini dengan memuat informasi dan penjelasan paling sedikit mengenai :

a. Jenis dan deskripsi umum produk dan/atau aktivitas baru;

b. Waktu penerbitan produk dan/atau pelaksanaan aktivitas baru;

c. Tujuan penerbitan produk dan/atau pelaksanaan aktivitas baru;

d. Keterkaitan produk dan/atau aktivitas baru dengan strategi bisnis bank;

e. Risiko atas penerbitan produk dan/atau pelaksanaan aktivitas baru; dan

f. Mitigasi risiko atas penerbitan produk dan/atau pelaksanaan aktivitas baru.

Berdasarkan uraian tersebut, kerja sama antara bank dengan penyelenggara Fintech P2PL dalam pengelolaan NPL adalah kerja sama yang merupakan aktivitas baru bank dimana untuk melaksanakan kerja sama tersebut, harus memperhatikan ketentuan POJK 18/POJK.03/2016, SEOJK 27/SEOJK.03/2016 serta ketentuan lain yang mengatur produk dan/atau aktivitas baru bank.

\section{Pengawasan terhadap Kerja Sama Bank dengan Penyelenggara Fintech Peer- to-Peer Lending}

Para ahli mengemukakan definisi pengawasan sebagai berikut:

1. Viktor M. Situmorang dan Jusuf Juhir

Pengawasan adalah setiap usaha dan tindakan dalam rangka untuk mengetahui sampai dimana pelaksanaan tugas yang dilaksanakan menurut ketentuan dan sasaran yang hendak dicapai. ${ }^{42}$

2. Sondang P. Siagian

Pengawasan adalah proses pengamatan dari pelaksanaan seluruh kegiatan organisasi untuk menjamin agar semua pekerjaan yang sedang dilakukan

${ }^{42}$ Adisasmita Rahardjo, Pengelolaan Pendapatan dan Anggaran Daerah (Graha Ilmu 2011).[15]. 
berjalan sesuai dengan rencana yang telah ditentukan sebelumnya. ${ }^{43}$

3. Sujamto

Pengawasan adalah segala usaha atau kegiatan untuk mengetahui dan menilai kenyataan sebenarnya mengenai pelaksanaan tugas atau kegiatan, apakah sesuai dengan semestinya atau tidak. ${ }^{44}$

4. Soekarno

Pengawasan adalah suatu proses yang menentukan tentang apa yang harus dikerjakan, agar apa yang diselenggarakan sejalan dengan rencana. ${ }^{45}$

\section{Kerja Sama Penyaluran Kredit (Collaborate in Lending)}

Pengawasan terhadap kerja sama antara bank sebagai pihak pemberi pinjaman dengan penyelenggara Fintech P2PL sebagai pihak penyelenggara, tercermin dalam ketentuan POJK 77/POJK.01/2016 diantaranya:

1. Pasal 32 ayat (1) dan ayat (2)

Bahwa penyelenggara wajib menggunakan istilah, frasa, dan/atau kalimat yang sederhana dalam bahasa Indonesia yang mudah dibaca dan dimengerti oleh Pengguna dalam setiap dokumen elektronik. Dengan pengecualian, apabila diperlukan, penyelenggara dapat menyandingkan bahasa lain dengan bahasa Indonesia dalam dokumen elektronik tersebut.

2. Pasal 36 ayat (1) dan ayat (2)

Penyelenggara dapat menggunakan perjanjian baku sesuai dengan ketentuan peraturan perundang-undangan. Adapun perjanjian baku tersebut dilarang:

a. menyatakan pengalihan tanggung jawab atau kewajiban penyelenggara kepada pengguna; dan

b. menyatakan bahwa pengguna tunduk pada peraturan baru, tambahan, lanjutan, dan/atau perubahan yang dibuat secara sepihak oleh penyelenggara

\footnotetext{
${ }^{43}$ ibid.

${ }^{44}$ Jum Anggraini, Hukum Administrasi Negara (Graha Ilmu 2012).[78].

${ }^{45}$ Viktor M. Situmorang dan Jusuf Juhir, Aspek Hukum Pengawasan Melekat dalam Lingkungan Aparatur Pemerintah (Rineka Cipta 1998).[20].
} 
dalam periode pengguna memanfaatkan layanan.

Selain itu, tercermin pula dalam ketentuan kewajiban dan larangan penyelenggara Fintech P2PL sebagaimana diuraikan dalam sub-sub bab pengawasan OJK terhadap penyelenggara Fintech P2PL. Adapun pelanggaran atas ketentuan tersebut, akan dikenai sanksi administratif oleh OJK sebagaimana ketentuan Pasal 47 ayat (1) berupa : “a. peringatan tertulis; b. denda, yaitu kewajiban untuk membayar sejumlah uang tertentu; c. pembatasan kegiatan usaha; dan d. pencabutan izin”. Sehingga, apabila disimpulkan, pengawasan terhadap kerja sama ini dilakukan oleh OJK sebagaimana pengawasan OJK terhadap penyelenggara Fintech P2PL.

\section{Kerja Sama Penjualan Investasi Ritel (Ritel Investment)}

Pengawasan terhadap kerja sama penjualan investasi ritel oleh bank kepada pengguna (pemberi pinjaman) layanan Fintech P2PL terbagi ke dalam dua bentuk kerja sama yang terjadi yaitu kerja sama penyediaan layanan perbankan digital dan kerja sama pertukaran data. Mengenai kerja sama penyediaan layanan perbankan digital, pengaturan pengawasan tercermin dalam ketentuan POJK 12/POJK.03/2018 diantaranya:

\section{Pasal 13 ayat (2)}

"Dalam melakukan kerja sama dengan mitra bank, bank tetap memperhatikan ketentuan peraturan perundang-undangan";

2. Pasal 15 ayat (1) dan ayat (2)

Mitra bank dalam melakukan penyediaan layanan transaksional adalah berupa: a. LJK dan/atau b. lembaga non-LJK. Adapun bagi mitra bank yang berupa penyedia layanan keuangan berbasis teknologi informasi, diwajibkan telah memperoleh izin dari OJK atau otoritas lain yang berwenang.

Mengenai kerja sama penyediaan layanan perbankan digital antara bank dengan penyelenggara Fintech P2PL, apabila disimpulkan, pengawasan terhadap kerja sama ini dilakukan oleh OJK sebagaimana pengawasan OJK terhadap bank umum. 


\section{Kerja Sama Pengelolaan Non-Performing Loan (NPL)}

Kerja sama pengelolaan NPL merupakan penerbitan produk dan/atau pelaksanaan aktivitas baru bank, dan untuk melaksanakannya, harus mencantumkan perencanaan dalam RBB dengan memuat informasi dan penjelasan atas:

a. Jenis dan deskripsi umum produk dan/atau aktivitas baru;

b. Waktu penerbitan produk dan/atau pelaksanaan aktivitas baru;

c. Tujuan penerbitan produk dan/atau pelaksanaan aktivitas baru;

d. Keterkaitan produk dan/atau aktivitas baru dengan strategi bisnis bank;

e. Risiko atas penerbitan produk dan/atau pelaksanaan aktivitas baru; dan

f. Mitigasi risiko atas penerbitan produk dan/atau pelaksanaan aktivitas baru.

Penulis merujuk pada ketentuan POJK 18/POJK.03/2016 Tentang Penerapan Manajemen Risiko Bagi Bank Umum, dimana pengawasan dalam hal risiko dan mitigasi risiko bank tercermin dalam ketentuan :

1. Pasal 2 ayat (1) dan ayat (2)

Bahwa bank wajib menerapkan manajemen risiko secara efektif, baik untuk bank secara individu maupun untuk bank yang berkonsolidasi dengan perusahaan anak dimana penerapan tersebut sedikitnya mencakup:

a. Pengawasan aktif direksi dan dewan komisaris;

b. Kecukupan kebijakan dan prosedur manajemen risiko serta penetapan limit risiko;

c. Kecukupan proses identifikasi, pengukuran, pemantauan, dan pengendalian risiko, serta sistem informasi manajemen risiko; dan

d. Sistem pengendalian intern yang menyeluruh.

2. Pasal 20 ayat (1) dan ayat (2)

Bahwa mengenai produk atau aktivitas baru bank, bank wajib memiliki kebijakan dan prosedur tertulis untuk mengelola risiko yang melekat daripada produk atau aktivitas tersebut sedikitnya mencakup:

a. Sistem dan prosedur (standard operating procedures) serta kewenangan dalam pengelolaan produk dan aktivitas baru;

b. Identifikasi seluruh risiko yang melekat pada produk atau aktivitas baru, baik yang terkait dengan bank maupun nasabah;

c. Masa uji coba metode pengukuran dan pemantauan risiko terhadap produk dan aktivitas baru;

d. Sistem informasi akuntansi untuk produk dan aktivitas baru;

e. Analisa aspek hukum untuk produk dan aktivitas baru; dan

f. Transparansi informasi kepada nasabah. 
Adapun mengenai pelanggaran terhadap ketentuan tersebut, akan dikenai sanksi administratif sebagaimana yang telah diuraikan dalam sub-sub bab 2.3.3. berdasarkan uraian di atas, apabila disimpulkan, pengawasan terhadap kerja sama ini dilakukan oleh OJK sebagaimana pengawasan OJK terhadap bank umum.

\section{Kesimpulan}

Kerja sama Bank Umum dengan Penyelenggara Fintech Peer-to-Peer Lending dalam 3 (tiga) bentuk kerja sama yaitu Kerja Sama Penyaluran Kredit (Collaborate in Lending), Kerja Sama Penjualan Investasi Ritel (Ritel Investment) dan Kerja Sama Pengelolaan Non-Performing Loan (NPL) berdasarkan analisis menggunakan pendekatan peraturan perundang-undangan terkait, diketahui bahwa Kerja Sama Penyaluran Kredit dilaksanakan dengan memperhatikan ketentuan mengenai layanan pinjam meminjam uang berbasis teknologi informasi sedangkan Kerja Sama Penjualan Investasi Ritel dan Kerja Sama Pengelolaan Non-Performing Loan dilaksanakan dengan memperhatikan ketentuan mengenai bank dan/atau bank umum sebagaimana dalam kerja sama bank umum.

Adapun pengawasan terhadap Kerja Sama Penyaluran Kredit merupakan tugas dan wewenang OJK sebagaimana OJK melakukan pengawasan terhadap Penyelenggara Fintech Peer-to-Peer Lending, sedangkan pengawasan terhadap Kerja Sama Penjualan Investasi Ritel dan Kerja Sama Pengelolaan Non-Performing Loan merupakan tugas dan wewenang OJK sebagaimana OJK melakukan pengawasan terhadap kegiatan usaha Bank Umum.

\section{DaftarBacaan}

\section{Buku}

Adisasmita Rahardjo, Pengelolaan Pendapatan dan Anggaran Daerah (Graha Ilmu 2011).

Airin, Perbandingan Karakteristik Layanan Pinjam Meminjam Uang Berbasis Teknologi Informasi (Financial Technology Peer To Peer Lending) Dengan Perbankan (Skripsi Pada Program Sarjana Universitas Airlangga 2017). 
Brett King, Breaking Banks, The Innovators, Rogues and Strategists Rebooting Banking (John Wiley \& Sons Singapore Pte.Ltd 2014).

Bryan A Garner (Ed.), Black's Law Dictionary Eight Edition (Thomas Reuters 2004).

Carissa Akhlaq Mulia Purnomo, Penyelenggaraan Sistem Dan Transaksi Elektronik Peer To Peer Lending Yang Disediakan Oleh PT Amartha Mikro Fintek (Skripsi pada Program Sarjana Universitas Airlangga 2018).

Jum Anggraini, Hukum Administrasi Negara (Graha Ilmu 2012).

Tati Febriyanti, Optimasi Portofolio Investasi Dana Syariah (Tesis Pada Program Pascasarjana Universitas Indonesia 2009).

Viktor M. Situmorang dan Jusuf Juhir, Aspek Hukum Pengawasan Melekat dalam Lingkungan Aparatur Pemerintah (Rineka Cipta 1998).

\section{Jurnal}

Ichsan Ferdinan S, 'Kewenangan Bank Indonesia Setelah Disahkan Undang-Undang Nomor 21 Tahun 2011 Tentang Otoritas Jasa Keuangan’ (2013) Private Law.

Jamaluddin, 'Konsekuensi Akad Al-Ariyah Dalam Fiqh Muamalah Maliyah Perspektif Ulama Madzahib Al-Arba’ah' (2015) 02 Jurnal Qawanin 2.

Jose-Luis Peydro, 'Discussion Of "The Effect Of Bank Capital On Lending : What Do We Know and What Does It Mean?"'(2010) 06 International Journal Of Central Banking 4.

Ryan Randy Suryono, 'Financial Technology (FINTECH) Dalam Prespektif Aksiologi' (2019) 10 Jurnal Masyarakat Telematika Dan Informasi 1.

Selamet Riyadi, 'Muhammad Iqbal dan Novia Lauren, Strategi Pengelolaan Non Performing Loan Bank Umum Yang Go Public' (2015) Vol 6 No. 1 Jurnal Dinamika Manajemen.

\section{Laman}

CNBC Indonesia TV, 'Ekonom Nilai Kolaborasi Fintech \& Bank Akan Menguntungkan', <https://www.cnbcindonesia.com/tech/2019100815505539-105301/ekonom-nilai-kolaborasi-fintech-bank-akan-menguntung>, dikunjungi pada 11 September 2020.

Deloitte, 'A Tale of 44 Cities - Connecting Global Fintech : Interim Hub Review 
2017', < <ttps://www2.deloitte.com/content/dam/Deloitte/uk/Documents/ Innovation/deloitte-uk-connecting-global-fintech-hub-federation-innotribeinnovate-finance.pdf $>$, dikunjungi pada tanggal 31 Oktober 2020.

Google, 'Partnership Meaning (definisi dari Oxford Languages)', <www.google. com>, dikunjungi pada 1 Desember 2020.

Investree, 'Bagaimana Cara Kerja Peer-to-Peer Lending?", <https://investree.id/ how-it-works>, dikunjungi pada 21 Desember 2020.

IpotNews, 'Kebijakan Makroprudensial Tetap Akomodatif Terhadap Perbankan 3-4 Tahun Ke Depan : BI', <https://www.indopremier.com/ ipotnews/newsDetail.php?jdl=Kebijakan_Makroprudensial_Tetap_ Akomodatif_Terhadap_Perbankan_3_4_Tahun_Ke_Depan_BI\&news_ $\mathrm{id}=106580 \&$ group_news $=I P O T N E W S \& n e w s \_d a t e=\&$ tagging subtype $=$ ECONOMICS \& name $=\& \operatorname{search}=y \_g e n e r a l \& q=$ kebijakan makro,perbankan\&halaman=1>, dikunjungi pada 12 November 2020.

Nina Dwiantika, 'BI Minta Nasabah Bank Gunakan Transaksi Derivatif', <https:// www.google.com/amp/s/amp.kontan.co.id/news/bi-minta-nasabah-bankgunakan-transaksi-derivatif $>$, dikunjungi pada 29 Desember 2020.

Sitti Mawar, 'Metode Penemuan Hukum (Interpretasi dan Konstruksi) Dalam Rangka Harmonisasi Hukum', <https://jurnal.ar-raniry.ac.id/index.php/ justisia/article/download $>$, diakses pada 22 Desember 2020.

Suhail Eresmair, 'Bank vs Fintech, Siapa Yang Akan Menang?', $<$ https://www.google.com/amp/s/www.kompasiana.com/amp/ suhailsuhail4643/5cc1591 da8bc1569e50ca0f2/bank-vs-fintech-siapa-yangakan-menang>, dikunjungi pada 12 November 2020.

VivaBudyKusnandar, '92 JutaPendudukDewasaIndonesiaBelumTersentuhLayanan Finansial', <https://databoks.katadata.co.id/datapublish/2019/10/08/92-jutapenduduk-dewasa-indonesia-belum-tersentuh-layanan-finansial $>$, dikunjungi pada 31 Oktober 2020.

Worldbank.org.ro, 'The History of Banks', <https://www.worldbank.org.ro/aboutbanks-history>, dikunjungi pada tanggal 24 Oktober 2020.

Yosepha Pusparisa, 'Pengguna Smartphone Diperkirakan Mencapai 89\% Populasi Pada 2025', <https://databoks.katadata.co.id/datapublish/2020/09/15/ penggunaan-smartphone-diperkirakan-mencapai-89-populasi-pada-2025>, dikunjungi pada tanggal 31 Oktober 2020. 


\section{Peraturan Perundang-undangan}

Undang-Undang Republik Indonesia Nomor 21 Tahun 2011 Tentang Otoritas Jasa Keuangan (Lembaran Negara Republik Indonesia Tahun 2011 Nomor 111).

Peraturan Otoritas Jasa Keuangan Nomor 18/POJK.03/2016 Tentang Penerapan Manajemen Risiko Bagi Bank Umum (Lembaran Negara Republik Indonesia Tahun 2016 Nomor 53).

Peraturan Otoritas Jasa Keuangan Nomor 77/POJK.01/2016 Tentang Layanan Pinjam Meminjam Uang Berbasis Teknologi Informasi (Lembaran Negara Republik Indonesia Tahun 2016 Nomor 324).

Peraturan Otoritas Jasa Keuangan Nomor 12/POJK.03/2018 Tentang Penyelenggaraan Layanan Perbankan Digital Oleh Bank Umum (Lembaran Negara Republik Indonesia Tahun 2018 Nomor 127).

Surat Edaran Otoritas Jasa Keuangan Nomoe 27/SEOJK.03/2016 Tentang Kegiatan Usaha Bank Umum Berdasarkan Modal Inti. 